\title{
Higher education as a factor of socio- economic performance and development
}

\author{
Vyacheslav Volchik \\ Southern Federal University, \\ Rostov-on-Don, Russian Federation \\ volchik@sfedu.ru
}

\section{Anna Oganesyan}

Southern Federal University,

Rostov-on-Don, Russian Federation

aaoganesyan@sfedu.ru

\section{Tadeusz Olejarz}

The Faculty of Management

Rzeszow University of Technology

Poland

olejarz@prz.edu.pl

Abstract. In the context of globalized markets and localized R\&D structures, tertiary (also called higher or university) education becomes one of the main factors facilitating economic performance. In the face of globalization and digitalization, substantial institutional changes, reforms and merges of universities represent a challenge for the higher education in the 21 st century. These changes go hand in hand with economic development and global economic growth as far as higher education significantly impacts economic performance of regions and countries. European Union (EU) also faces these challenges and therefore has to promote higher education policies and invest into tertiary education in order to increase the level of human capital of its citizens with the purpose of achieving competitiveness on the global markets and higher economic growth. Our paper focuses on the reforms in higher education that are currently taking place worldwide and employ best practices occurring in universities throughout the world. In particular, we show that higher education has a positive impact on the economic performance as well as on the individual social and economic performance. We employ an empirical model that demonstrates the tertiary
Received:

June, 2018

1st Revision:

October, 2018

Accepted:

December, 2018

DOI:

$10.14254 / 2071$ $8330.2018 / 11-4 / 23$ 
education has a significantly positive economic outcome for local citizens, EU citizens and third-country nationals on the example of the Federal Republic of Germany, EU largest economy and a major hub for higher education. Moreover, we compare the situation of immigrants from the EU and non-EU countries and their level of returns to higher education. Overall, it appears that current system of higher education requires deeper institutional reforms that would both reflect opening up of the EU to migrants from various non-EU countries with implication for its labour market, and recent trends in higher education. Our results might prove to be resourceful for researchers, academics, educators, policy-makers as well as for the stakeholders in higher education.

Keywords: higher education, universities, economic performance, labour market, regional development, structural reforms.

JEL Classification: I23, P11, R11

\section{INTRODUCTION}

The processes of reforming higher education are now becoming crucially important for social life as well as business and economics. On the one hand, reforms of higher education are associated with more general problems of reforming the public sector, and on the other, it is aimed at optimizing and increasing the efficiency of specific universities (Degn \& Sørensen, 2015; McKelvey \& Zaring, 2018). Reorganization, unification and change of organizational structure at universities is carried out in a specific institutional environment. The specific characteristics of institutional environment are typically determined by national, regional, historical, cultural, legal, and other social factors that influence the structuring of recurring social interactions (Č́belková et al., 2017). Theoretical and research tools of interpretive institutional economics provide an opportunity to analyse the qualitative aspects of the reform and organizational changes in reorganized universities and Higher Education Institutions (HEIs).

In the neoliberal discourse, reforming and, in particular, merging of universities is considered by analogy with business processes, where the main motive is to increase economic efficiency. Steve Fuller gives an example of the activities of Richard Sykes, who was appointed the rector of Imperial College London based on the successful merger of two transnational pharmaceutical corporations (Fuller, 2009). Sykes' activities at the post of rector were also associated with the attempts to unite universities which reflects the trend towards a market-oriented approach in reorganization of universities.

Reforming universities significantly affects their autonomy. Within the framework of new universities, new hierarchies emerge, which, as they develop, are less and less related to the structure of united organizations. The merger of several universities leads to the formation of new internal regulations, management structures, as well as further reorganization of educational and scientific units. Emerging local institutions form the space of opportunity for actors, new incentives and behavioural patterns. Institutions and incentives are relevant for research on the economic behaviour of actors in the education system. However, it remains a nontrivial question. What are the relationships between changes in incentives and changes in institutions? One can state there is a certain dichotomy in this regard. This makes it possible to distinguish two types of mutual influence: first, changing institutions change the incentives for actors (Hodgson, 2003), second, changing incentives change institutions (Olson, 1995). Institutions and incentives are subject to mutual influence and the choice to analyse their changes of the first or second type depends on temporary, organizational, resource and other contexts. There is extensive literature already available on 
the relationship between institutions of incentives and economic policy (Navaretti et al., 1998; Gerber and Gibson, 2009). Institutions that have undergone changes in the process of reforming universities, for example, during mergers and reorganizations, in order to preserve efficiency, should be complementary both to the state policy in the field of education and to the existing informal institutions of academic environment. Complementarity of changes is associated with the mechanisms supporting the existence of the institution (Dacin et al., 2010; Zilber, 2009). In other words, stability of the institution and the factors supporting it are significant if we have reliable data available for a certain period of operations (existence of the institution). In addition, one can see that development of the tertiary education sector bears eminent importance in the context of current economic development (Li et al., 2018).

This paper is structured as follows: Section 2 provides a comprehensive literature review of the institutional and organizational mechanisms for the reforms and roles of the universities in the context of the regional and national socioeconomic development. Section 3 outlines our methodology and data employed for the empirical econometric model based on the Mincer's equation and testing the returns to higher education on the example of locals, EU citizens and third-country nationals in the Federal Republic of Germany, the EU largest economy up to date. Section 4 presents the empirical model, reports its main results and implications and discusses them in detail. Finally, Section 5 comes with some closing remarks and provides conclusions and discussions for the paper.

\section{LITERATURE REVIEW}

According to the Times Higher Education ranking, the top ranked university in the world in 2018 was the University of Oxford (Times Higher Education, 2018). From the same report, it appears that it was closely followed by University of Cambridge, California Institute of Technology, Stanford University, and the Massachusetts Institute of Technology (MIT) which closed the top five positions. Thence, only two European universities made it to the Top 5 and most of the Top 20 universities are from the United States. In any industry, or sector, where there are multiple players, firms, or institutions, they all do not perform at the same level; some will perform better than others. This situation has given rise to the ranking system, as is the case in the global universities ranking described above, in which firms, businesses, organizations, or institutions, depending on the industry, are ranked premised on their order of performance as measured using different performance measures or indicators. For example, there are different rankings, such as the Forbes 500 ranking, universities rankings, and best employers' rankings, and other similar rankings systems in the world. Under this system, it is assumed that the organizations that rank above the others formulate and implement strategies and activities that foster good performance, propelling them over the competition.

Firms that outperform or record better performance than other firms in the industry are deemed as having best practice. According to Hinton et al. (2000), best practices are aspects of the operations of a business that have been identified, tested, and verified to produce good results. In the pursuit of improvement and excellence, firms that have recorded lower levels of performance, compare their processes and practices against the best practices of the leading firms in the industry. Indeed, according to Zairi (2010) in total quality management, firms identify and use best practices to benchmark and improve their operations to achieve improvement in different performance aspects. Benchmarking, according to Francis and Holloway (2007), is the process of continuously comparing the processes and operations or other performance aspects to industry best practices or best practice of leading firms in the industry or other industries with an objective of improving the performance of a firm. Borrowing from best practices and benchmarking philosophy and strategy, premised on the best practices of the top ranked institutions, universities pursuing a continuous improvement strategy, can formulate and implement strategies that will enable them to achieve better outcomes in terms of the different performance measurement metrics. 
In the global universities' ranking by Times Higher Education, and other institutions that provide similar or near similar rankings, there are different parameters that are assessed and scored. Subsequently, premised on a comparison of the scores of the different institutions, the institutions that have higher cumulative scores are ranked higher than those with lower cumulative scores (Gulicheva \& Osipova, 2017). Evidently, this system bears all the essential features of a best practices and benchmarking philosophy, which as Zairi (2010) observed, involves identifying key performance indicators or metrics for assessing performance. In this case particularly, the metrics or the parameters used in the ranking are derived from the core mission of institutions of higher learning, including teaching, research, knowledge transfer, and international outlook (Gunter and Raghuram, 2018; Radwan, 2018).

More particularly, according to Chigisheva et al. (2017), Naushad et al. (2018) or Naushad (2018), in teaching, the assessors sought to evaluate the teaching environment; in research, they evaluated the volume of research, income, and reputation; citations were used to assess research influence; international outlook evaluated diversity or inclusion among staff, students, and in research; and industry income assessed the impact of the institution on knowledge transfer. The data and results used in the analysis and ranking of these institutions were audited by PricewaterhouseCoopers at different intervals. This approach fostered the validity and credibility of the institutions. As such, from these metrics, or the performance indicators used in the study, it is possible to identify and evaluate the different challenges that universities face premised on the key performance indicators identified.

Associated with the particular metrics used in the ranking, are different factors, which if not addressed, emerge as challenges to the competitiveness of universities. One of the challenges or factors associated with the learning or teaching environment is the faculty to student ratio. Ideally, the number of students to a teacher is supposed to remain as low as possible to enable the teachers or faculty to provide personalized instructions. Indeed, according to Yu et al. (2016) or Bordean and Sonea (2018), faculty to student ratio is a major determinant of the levels of interaction between students and faculty, and so influence student engagements.

Furthermore, from a scrutiny of the top ranked universities shows that they have a student to teacher ratio starting as low as 4 , and not higher than 20 . These statistics intimate that the teachers are able to personalize their interactions with the students. On the other hand, the Universities ranked lowest have high student to teacher ratio, with universities such as Yazd University having a ratio of 23.9 and Yeditepe with a ratio of 25.1, which are all ranked above 1001 (Times Higher Education, 2018). Evidently, a best practice associated with this particular metric is a ensuring a low student to teacher ratio.

Other factors associated with the learning environment and have an impact on the rating and ranking are the female to male students' ratio, international students and gender parity. With globalization, and in line with the general mission of universities as elucidated by Times Higher Education (2018), it is important for universities to put in place measures to attract international students, faculty, and staff. Among the top ranked universities, international students make up a large portion of the student population, with some of the universities, such as Imperial College in London, ranked number 8, international student's make up approximately $55 \%$ of the students' population. On the other hand, among the Universities ranked above 1001 , international students make up about $1 \%$ of the student population.

However, it is important to note that some of the universities ranked lowly, have high numbers of international students. Evidently, driven by different factors, it is evident that some of the universities ranked among the lowest have not been able to attract adequate number of international students, which could be an impediment to the achievement of the mission of universities in a globalized environment. According to Hegarty (2014), international students foster diversification and multicultural awareness and education of students, which enable the university and students by extension to excel in a multicultural global environment. 
Similarly, gender diversification, or having a student population that has male and female students' parity, fosters the achievement of not only the particular university's goals, but also contributes to the achievement of global goals and objective of fostering gender equality (Nuamah, 2018). Gender parity achieved by gender diversity contributes to gender parity in other areas of the economy and enhances equality in the national and by extension, international economies and the society (Costa et al. (2015). A scrutiny of the female to male ratios among universities on the list, shows a lot of progress towards the achievement of gender parity in the students' population.

Female to male ratios are nearly uniform across the universities. Some universities, such as the National University of Singapore and London School of Economics and Political Science having larger female students' population and are ranked among the top 20. Similarly, Yeditepe University and University of Zanjan, which are ranked at 10001+, have higher female to male students' ratios at 52:48 and 55:45 respectively. Collectively, the factors associated with the learning environment contribute to challenges in other areas, such as research and overall performance of students, as well as lower persistence, retention, and graduation rates.

There are other challenges that universities face, which may impede their abilities to implement best practices in their operations. These challenges include the increasing cost of education, government policy and regulation covering issues such as standards and financial aid, lack of adequate financial resources, lack of physical infrastructure (Drape et al., 2016), depreciating value of the college degree, technological changes, lack of alignment of curriculum and university agenda to the demands of the labour market (Sharma \& Sharma, 2015), and the role of extra-curriculum activities in education (Ramaley, 2014). Collectively, these challenges make it impossible for universities to implement best practices. For example, the lack of adequate financial resources, will make it difficult for the institutions to hire and retain faculty, while the lack of physical infrastructure means that students do not have facilities such as classrooms, laboratories, and other similar facilities required to excel in academics. As such, in order to succeed, universities have to recognize these challenges and formulate and implement corrective actions.

Within the presented context, reorganization and merges of universities represents a continuation of the state policy in the field of higher education and affects both public and private universities. However, in the context of some countries where the share of private universities is insignificant, this reorganization mainly affects the state. It is very important to understand what goals are pursued when deciding on reorganization. Explicitly declared goals may differ from the implicitly realized intentions. For example, the explicit goals of optimization and efficiency gains can be realized along with the implicit goals of reducing funding and the number of students studying for budget funds.

Generally, it appears crucial to consider the reforms in the field of education in the light of the complementarity of institutional and organizational changes. These changes typically occur when one or more institutions reinforces the effect of other institutional changes (Ahrens \& Jünemann, 2010). The reform associated with the institutional changes sets the development trajectory, where the consistency of a given set of institutions is determined by the additional characteristics of the institutions themselves. This property of complementarity is fundamental to determine the coherence, structure and development of an economic system (Amable, 2015).

However, institutions do not always show signs of complementarity to the innovations being introduced. This is due to the time lags between reforms and the formation of an effective institutional structure (Streeck \& Thelen, 2005). Therefore, in the process of creating and/or reforming the institution, the experimental component plays a decisive role. Rules that are externally imposed can push cooperative behaviour that has arisen endogenously (Ostrom et al, 1994). In the new management hierarchy, the lowest effectiveness of institutions arises in a system with strong external monitoring and sanctions with a low role 
of internal norms. In the case of higher education, legislative regulation should be sustainable and consistent, and not measures of rapid response.

Institutional complementarity in the field of education is an insufficiently unsystematic studied topic. With regard to the reforms and mergers of the universities, Azziz et al. (2017) note that any merger which involves more than two institutions (although undoubtedly more complex) still retains the fundamental characteristics associated with similarity, complementarity, and system (Azziz et al., 2017).

Analysing the complementarity of organizational changes in the educational sphere, in particular, during the merger of universities, some authors point out the importance of analysing the complementarity of changes in informal institutions (see Harman \& Harman, 2003). Usually, higher education institutions combined as the adaptively complex systems must be complementary not only in terms of target quantitative indicators, but also in the context of their missions, organizational cultures and behavioural patterns (Harman \& Harman, 2003; Volchik, 2016; Lazányi et al., 2017; Kriaa \& Bouhari, 2018). Thus, it is necessary to take into account the complementarity of not only changes in formal institutions, but also informal ones, since it is in them that potential conflicts of interest are inherent (Alesina \& Giuliano, 2015).

\section{METHODOLOGY AND DATA}

Nowadays, in a situation when the globalization if the markets and localization of science related industries make tertiary education vital for economic well-being of the countries, the interdependence between the tertiary education and economic performance becomes apparent. As economic growth becomes more dependent on high-technology industries universities get function of main source of the R\&D-based growth (Guerrero et al. 2015; Marozau et al., 2016; Fägerlind \& Saha, 2016).

There are a number of ways how the university education influences economic performance: First, the university provides a greater supply of educated workforce which is important for economic growth (Sianesi \& Van Reenen, 2003; Gennaioli et al, 2013), besides others by economic spill-overs (Moretti, 2004; or Glaeser \& Lu, 2018). Second, universities deliver more innovations including managerial innovations (Bloom et al. 2017) and, possibly, new economic subjects such as spin-off firms. Third, universities increase the demand for certain goods and services. Last but not least, universities provide institutions which support democratic and economy-related values (Acemoglu et. al., 2005).

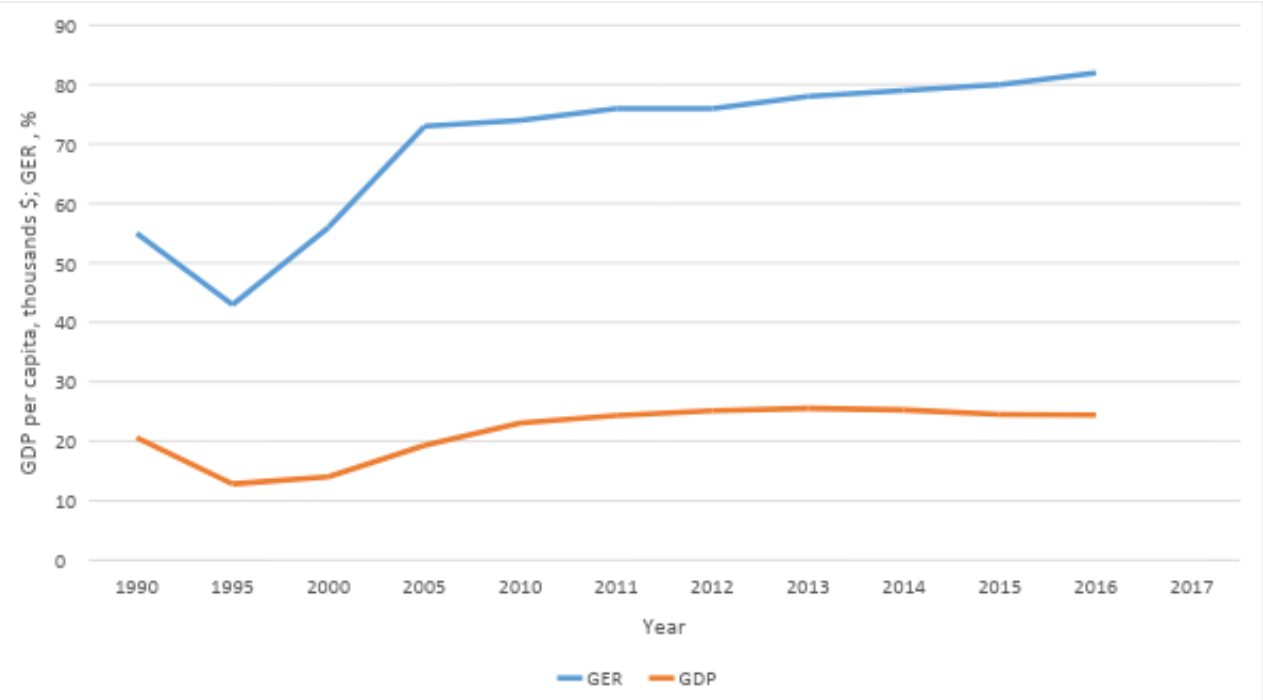

Figure 1. GDP per capita and gross enrolment ratio for tertiary education ( $\%$ of tertiary school-age population) between 1990 and 2017

Source: United Nations (2018) 
With regard to the above, Figure 1 demonstrates the strong relationships between GDP per capita and gross enrolment ratio for the universities (tertiary education) based on the Human Development Index data (1990-2017), a dataset collected within a project run by the United Nations (2018). One can notice the pattern showing that an increase in university enrolment tend to coincide with the rise of GDP per capita.

In this paper, we will focus on the economic outcomes of higher education in terms of its impact on the labour markets within regions or countries. There are a number of studies that deal with the education as a form of return on investment in human capital (see e.g. Blanchard \& Olney, 2017). However, the first and the most basic causation was proposed by Mincer (1974) in his classical work (and subsequently polished later in his mater works such as Mincer \& Polachek, 1978). In general, Mincer equation has the following form:

$$
\ln Y_{S}=\ln Y_{0}+\beta_{1} t+\beta_{2} t^{2}+r s
$$

where $\mathrm{Ys}$ is the income in the objected year, $\mathrm{Y}_{0}$ is initial income, $\mathrm{s}$ years of schooling, $\mathrm{r}$ interest rate, and $t$ represents the number of years at a job.

According to (1), wage income is a function of schooling and experience, meaning that the higher is the individual's level of education, the better off she or he is going to be on the labour market. The obvious conclusion would be that higher education means higher wages and better position on the economic and social ladder.

Many studies were conducted to verify this causation in many countries and the results appeared to be always the same. For example, in accord with the above methodology, Brunello et al. (2004) applied regression models on panel data from Italy and pointed out that years of education was not a random variable but the one subjected to individual decisions and, at the same time, depending on the education and other characteristics of the parents. The study showed that education and the accumulation of human capital in the labour market were complementary meaning that individuals with higher education were more likely to invest in further education or schooling even after graduation. In addition, Bratsberg and Ragan (2002) or Ferrer and Riddell (2008) on the examples from United States or Canada show that years of education and practice in the country of origin have a much lower value in the target country than the same education period in the target country. In addition to years of education, the study includes both a factor in investing in human capital and the level of education attained. The authors point out that there are differences between people on the labour market linked to their higher returns on education.

For the purpose of this study, we will focus on the case of the Federal Republic of Germany, the EU largest economy and the country with the largest labour market and the highest share of international migrants (Schoper et al., 2018; Streimikiene et al., 2016; Simionescu et al., 2016). This country represents a specific and peculiar case for studying due to the fact that it is profound in higher education as well as excels in economic performance (Hüther \& Krücken, 2018).

Ammermüller and Weber (2005) carried out a study to measure the return on education in income across the population of the Federal Republic of Germany. The study is based on the theory of human capital and finds that income differentials are mainly gender and regional. They concluded that there was a higher return on investment in education (measured through the title) among women than among men. The return of academic education was found to be higher across populations than in other grades. Moreover, Boockmann and Steiner (2006) investigated return on investment as the hourly wage logarithm of German residents excluding specific groups (students, soldiers, pensioners or clerks). Their study focused on comparing groups of people by year of birth and extended Mincer equation (1) to include other variables such as personal characteristics $\left(Z_{i t}\right)$ or the qualitative variable represented by the dummy $\left(\mathrm{D}_{\mathrm{ik}}\right)$ and signifying whether the person is a member of the group. The resulting model is presented in equation (2) that follows: 


$$
\ln W_{i t}=\beta_{0}+\beta_{1} X_{i t}+\beta_{2} X^{2}{ }_{i t}+\sum \beta_{k} D_{i k}+\sum \gamma D_{i k} S_{i}+Z_{i t} \zeta+u_{i t}
$$

Therefore, we will employ the above methodology in order to test the impact of higher education on the economic well-being (performance on the labour market) using a special case study of Germany.

The data used for our empirical model were obtained from the Federal Statistics Office of Germany (Distatis, 2018) and German Institute for Economic Research (DIW, 2018). The data includes observations on several thousand individuals residing in Germany for the period of 1990-2017 and features many personal and economic characteristics, including the years of schooling, highest level of education, as well as economic performance (income, position on the labour market, etc.). We restricted our observations only to the population of respondents born after 1950 because people born after this year constitute the active workforce in Germany.

\section{EMPIRICAL MODEL RESULTS AND IMPLICATIONS}

Our empirical model is envisaged to test the causality between higher education and socio-economic performance. We are aiming at determining whether there exists return to higher education in terms of higher earnings and better status on the labour market. Our model compares three groups of respondents based on their background and nationality: the Germans, EU citizens residing in Germany and migrants from the third countries. Our dependent variable is the average monthly gross income. The variable was created by dividing the annual income by the number of months worked during the respective year. The gross income was used due to the fact that it is not affected by the level of taxation which can different for various income groups.

Firstly, we checked the presence of unit root in the data series for all variables. According to ADF test, the data series for all variables are stationary at $10 \%$ level of significance. VIF was computed to check for multicollinearity and there is no significant evidence for the presence of correlation between explanatory variables. For the proposed models, we checked the independence and the homoskedasticity of errors. According to Breusch-Godfrey test, for a lag equalling to 1, there is not any serial correlation of order one for the errors in the case of all proposed models. The errors were heteroskedastic at 5\% level of significance. The p-values associated to White test were: 5.21181E-009, for the first sample, 7.38274E-043 for the second sample and 5.8312E-082 for the third sample. It is apparent that all models reveal the absence of homoscedasticity and therefore should be treated with an adjusted OLS model.

Thence, we use ordinary least squares (OLS) regression with robust standard errors (in order to take care of heteroskedasticity and its impact on the coefficient errors). The results of the first model encompassing three samples of respondents is presented in Table 1 below.

In accordance with our expectations, the number of years spent in higher education has a positive impact on the social and economic performance measures by the level of income. In addition, the number of years of full-time and part-time work also have a significantly positive effect on the level of earnings. Moreover, each additional hour worked weekly would increase personal revenue by 4.6 percentage points. On the other hand, unemployment experience (measured in years of being unemployed) has a negative impact on income. There is also a gender inequality present - it appears that women earn less than men by almost 5\%. Furthermore, the region in which the person lives and works also has a significant impact on the level of income. From the results of our model, it appears that compared to the reference group, the old Länder (territories belonging to the Federal Republic of Germany after WWII), people in the new Länder (territories belonging to the Democratic Republic of Germany (GDR) after WWII) and Berlin have lower incomes. 
Table 1

Results of OLS with robust standard errors between average monthly income and the level of education for German citizens and residents (1990-2017)

\begin{tabular}{|c|c|c|c|}
\hline Average monthly income & Sample 1 & Sample 2 & Sample 3 \\
\hline Intercept & $6.458 * * *$ & $7.993 * * *$ & $5.959 * * *$ \\
\hline Years of schooling & $0.224 * * *$ & $0.019 * * *$ & $0.012^{* * *}$ \\
\hline Years in employment & $0.089^{* *}$ & $0.067^{* *}$ & $0.021 * * *$ \\
\hline Years in employment ${ }^{\wedge} 2$ & $-0.002 * *$ & $-0.002^{* *}$ & \\
\hline Experience`2 $^{\wedge}$ & $-0.002 * * *$ & $-0.002^{* * *}$ & \\
\hline College education & & $0.113^{* * *}$ & \\
\hline Technical education & & $0.282^{* * *}$ & \\
\hline School education & & $0.569^{*}$ & \\
\hline Part-time employment & & & $0.007^{* *}$ \\
\hline Unemployment experience & & & $-0.077^{* *}$ \\
\hline Hours at work per week & & & $0.046^{* * *}$ \\
\hline Female & & & $-0.204 * * *$ \\
\hline Employed in former GDR & & & -0.449 \\
\hline Employed in Berlin & & & $-0.264 * * *$ \\
\hline Working abroad & & & $0.205^{*}$ \\
\hline Foreigner & & & $-0.003^{* * *}$ \\
\hline $\mathrm{N}$ & 7607 & 7201 & 7201 \\
\hline R-squared & 0.679 & 0.611 & 0.606 \\
\hline
\end{tabular}

Note: ${ }^{* * *} \mathrm{p}<.001 .,{ }^{* *} \mathrm{p}<.01 .,{ }^{*} \mathrm{p}<.05 .$, and $\mathrm{p}<.10$

Source: Own results

Furthermore, we will test the differences between average monthly income and the level of education for EU citizens and third-country nationals residing in Germany using only the significant variables from the previous model. The selection of variables and the final model set were reached by the method of backward stepwise regression. Backward stepwise regression is used in order to explain and defend the use of candidate variables in regression models in which the choice of predictive variables is carried out by an automatic procedure. The procedure is run with the use of a sequence of F-test, t-tests, adjusted R-square, Bayesian information criterion, Mallow's Cp or false discovery rate (see e.g. Chen and Howard, 2016). Backward step regression used in our paper started with the initial model that contains all the independent variables. Then one variable is deleted at each stage (at first the variable that causes the smallest drop in adjusted R-squared is dropped) until the most optimal model is reached.

Table 2 that follows reports the results of the empirical model measuring the differences between average monthly income and the level of education for EU citizens and third-country nationals between 1990 and 2017. For the proposed models, we checked the independence and the homoskedasticity of errors. According to Breusch-Godfrey test, for a lag equalling to 1, there is not any serial correlation of order one for the errors in the case of all proposed models. The errors were heteroskedastic at $5 \%$ level of significance. The p-values associated to White test were: $5.85 \mathrm{E}-135$, for the first sample, $3.22 \mathrm{E}-08$ for the second sample and 0.00019 for the third sample. It is apparent that all models reveal the absence of homoscedasticity and therefore should be treated with an adjusted OLS model. 
Differences between average monthly income and the level of education for EU citizens and third-country nationals (1990-2017)

\begin{tabular}{|l|c|c|}
\hline \multicolumn{1}{|c|}{ Average monthly income } & Third-country nationals & EU citizens \\
\hline Intercept & $6.222^{* * *}$ & $6.597^{* * *}$ \\
\hline Years of schooling & $0.081^{* * *}$ & $0.062^{* * *}$ \\
\hline Years in employment & $0.036^{* *}$ & $0.034^{* *}$ \\
\hline Hours at work per week & $0.040^{* *}$ & $0.037^{* *}$ \\
\hline Female & $-0.221^{*}$ \\
\hline Command of language & $-0.173^{*}$ & 0.332 \\
\hline \multicolumn{2}{|c|}{} \\
\hline $\mathrm{N}$ & $0.284^{* * *}$ & 185 \\
\hline R-squared & 420 & 0.591 \\
\hline
\end{tabular}

Note: ${ }^{* * *} \mathrm{p}<.001 .,{ }^{* *} \mathrm{p}<.01 .,{ }^{*} \mathrm{p}<.05$, and $\mathrm{p}<.10$

Source: Own results

The results of our second model show that that the years of schooling years in employment and the command of German languages are all significant and positive in relation to the economic and social individual performance. Especially, the knowledge of German language plays a crucial role in determining income. Foreigners who have a good command of German earn almost 19 percentage points more than those who do not. Our regression model shows that foreigners have lower incomes than Germans. Also, the return to education in general (and higher education in particular) is lower for foreigners than for German citizens. Thence, an investment in education for foreigners would likely have a better impact on social and economic performance than demographic variables.

Overall, both our models show that education enhances economic and social wellbeing better than other factors. It might be useful to take this into account when planning whether to attend schools and universities and how much to invest into this. It appears that higher education might become a stepping stone to a better future for many young people not only in Germany or European Union, but in the other countries and regions. The stakeholders responsible for the reforms of the universities in the $21^{\text {st }}$ century should take this into account and adjust their strategies accordingly.

\section{CONCLUSIONS AND DISCUSSIONS}

All in all, our results indicate that while the correlation between the returns to higher education and individual socio-economic performance comes through as envisaged, more research is needed on this topic. On one hand, the highly educated labour, the positive externalities, R\&D and the spin-offs can impact the economic development directly. On the other hand, higher economic growth provides the economic and knowledge base for higher education. In any case, in order to make the most effective use of existing educational system and to develop it further, certain substantial changes in the higher education systems are necessary. Our paper argues that these changes should take into account the best practices of world leading universities in the best performing countries.

Evidently, there are different factors or challenges that impede the achievement of higher quality in university education across the board. It is therefore imperative, for a university, to ensure low student to teacher ratio, which is considered a best practice. To realize improved performance and improvement in the quality of higher education, in line with the principles of best practices and benchmarking; adoption and implementation of best practices from the leaders in the industry (Zairi, 2010; Strielkowski et al., 2018). 
Moreover, universities in all countries should adapt and implement practices put in place by the leading institutions - typically those to be found higher up in the global rankings. Accordingly, with the challenges or the problem areas identified, universities can formulate and implement mitigating actions in conformity with the best practices in the industry.

Institutions of higher education should adapt and implement different initiatives that will improve the learning experience of the students. To do so, these institutions need to increase the number of faculty or teachers. Identify, recruit, and retain faculty staff to achieve a lower student to faculty ratio to foster an improved learning experience for the students for better learning outcomes, such as improved persistence, retention, and graduation rates. As described by Yu et al. (2016), lower student to faculty ratios foster good interactions between teachers and students, and subsequently, result in an improved learning experience. In addition, in line with the practice of the leading institutions, universities should put in place different measures, including excellence in teaching and research, which will enable them to attract and retain faculty and students internationally to grow in stature.

Furthermore, in order to achieve better quality, the management and administration and the government, as well as other stakeholders involved in policy and strategy formulation, as well as the resources allocations, should ensure that financial resources are set aside for development and operational activities in these higher educational institutions. Generally, they should ensure that they operate in line with industry and global standards in different operational areas, which will propel them to achieve higher quality in education and subsequently, be ranked among the best in the industry. Collectively, such efforts will lead to a general improvement in the quality of tertiary education.

The success of the policy of state reform of higher education in any given country can only be achieved if the sustained nature of the proposed cooperation between key parties is not undermined by dysfunctional commercialization trends as part of the implementation of the New Public Management (NPM) methods, which leads in particular to precarization of labour relations in higher education (Volchik et al., 2018).

On would probably agree that it is necessary to involve relevant stakeholders interested in the effectiveness of modern higher education in the development and implementation of reforms either directly or indirectly: the academic community (teachers, researchers and students), administrative staff of universities, government officials, parents of schoolchildren and students, potential graduate employers, and universities - business enterprises and organizations (stakeholders), media representatives and nongovernmental NGOs.

It becomes clear that institutional reforms based on the policy of new management in reforming universities (New Public Management) lead to high transaction costs as a direct result of stricter control, increased formalization and bureaucratization in the educational process, along with an increase in the administrative burden on the academic community that accompanied the reform process over the past decade and at the present time, it is difficult for the teaching staff and research staff to realize their direct duties - Making an educational and training functions.

Moreover, evaluation of the effectiveness of management hierarchies in the merger of universities was made from the standpoint of qualitative analysis. In particular, such positive intra-organizational factors have been identified, associated with an increase in the efficiency of functioning of universities formed as a result of the merger as: an increase in centralized internal grants; support of innovative projects in the field of natural science and humanities; expansion of technological infrastructure; development of internal mobility of teachers; development of interdisciplinary interactions leading to the synergistic effect of the research.

Furthermore, significant factors in the reform of universities can be considered the loss of newly formed structural divisions of federal and basic universities of autonomy in carrying out financial calculations, an increase in the degree of regulation of operations associated with the expenditure of 
university funds by structural units the increase in the administrative burden on the management of structural units, faculty and researchers at not well-established electronic document management, the prevalence of rationing / rationing transactions (in the terminology of Commons (2012) prevents the effective implementation and development of market principles of universities, the establishment of effective schemes of interaction with enterprises and organizations in the region.

Overall, it appears that a key task in terms of the development of reformed universities is to provide effective feedback forms with representatives of all communities affected by the reform processes of the higher education system, in particular - by merging universities in the region, in particular - initiate a regular discussion of the elements of the implemented and planned reforms with the involvement of the scientific community (NRP, administrative staff of universities, students), parents of students and high school students, regional and municipal authorities, employers her, the media, and the NGOs.

\section{ACKNOWLEDGEMENT}

This paper was supported by the Ministry of Education and Science of the Russian Federation, Project No. 26.6124.2017/8.9 "Identification of institutions and organizational mechanisms for the merger of universities in the context of the socioeconomic development of the region".

\section{REFERENCES}

Acemoglu, D., Johnson, S., Robinson, J.A., \& Yared, P. (2005) From education to democracy?. American Economic Review, 95(2), 44-49. doi: 10.1257/000282805774669916

Ahrens, J., \& Jünemann, P. (2010). Transitional institutions, institutional complementarities and economic performance in China: A'Varieties of Capitalism'approach (No. 2010-11). Ordnungspolitische Diskurse

Alesina, A., \& Giuliano, P. (2015). Culture and Institutions. Journal of Economic Literature, 53(4), 898-944. doi: $10.1257 /$ jel.53.4.898

Amable, B. (2015). Institutional complementarities in the dynamic comparative analysis of capitalism. Journal of Institutional Economics, 12(01), 79-103 doi: 10.1017/s1744137415000211

Ammermüller, A., \& Weber, A. M. (2005). Educational attainment and returns to education in Germany. Centre for European Economic Research Discussion Paper 5/2005. Retrieved from: https://papers.ssrn.com/sol3/papers.cfm?abstract_id=711063\#\#

Azziz, R., Hentschke, G.C., Jacobs, B.C., Jacobs, L.A., \& Ladd, H. (2017). Mergers in higher education: A proactive strategy to a better future?. New York, NY: TIAA Institute.

Bilan, Y., Cabelkova, I., \& Strielkowski, W. (2015). State taxes and cultural values: Evidence from the microeconomic data. Actual Problems of Economy, 164(2), 108-116.

Blanchard, E. J., \& Olney, W. W. (2017). Globalization and human capital investment: Export composition drives educational attainment. Journal of International Economics, 106, 165-183. doi: 10.1016/j.jinteco.2017.03.004

Bloom, N., Lemos, R., Sadun, R. and Van Reenen, J. (2017) Healthy Business? Managerial Education and Management in Healthcare, NBER Working Paper No. 23880. Retrieved from: https://www.nber.org/papers/w23880.

Boockmann, B., \& Steiner, V. (2006). Cohort effects and the returns to education in West Germany. Applied Economics, 38(10), 1135-1152. doi: 10.1080/00036840500439168

Bordean, O.N., \& Sonea, A. (2018). Student satisfaction and perceived skills: any link to employability? Entrepreneurship and Sustainability Issues, 6(1), 356-370. doi:10.9770/jesi.2018.6.1(22)

Bratsberg, B., \& Ragan, J. F. (2002). The impact of host-country schooling on earnings: A study of male immigrants in the United States. Journal of Human resources, 37(1), 63-105. doi: 10.2307/3069604

Brunello, G., Lucifora, C., \& Winter-Ebmer, R. (2004). The wage expectations of European business and economics students. Journal of Human Resources, 39(4), 1116-1142. doi: doi.org/10.2307/3559041 
Č́belková, I., Normann, R., \& Pinheiro, R. (2017). The role of higher education institutions in fostering industry clusters in peripheral regions: Strategies, actors and outcomes. Higher Education Policy, 30(4), 481-498. doi:10.1057/s41307-017-0059-3

Chigisheva, O., Soltovets, E., \& Bondarenko, A. (2017). Internationalization impact on Ph.D. training policy in Russia: Insights from the comparative document analysis. Journal of Social Studies Education Research, 8(2), 178-190. doi:10.17499/jsser.360872

Chen, F. H., \& Howard, H. (2016). An alternative model for the analysis of detecting electronic industries earnings management using stepwise regression, random forest, and decision tree. Soft Computing, 20(5), 1945-1960. doi:10.1007/s00500-015-1616-6

Commons, J. R. (2012). Institutional Economics. Terra Economicus, 10(3), 69-76.

Costa, A. B., Peroni, R. O., de Camargo, E. S., Pasley, A., \& Nardi, H. C. (2015). Prejudice toward gender and sexual diversity in a Brazilian Public University: prevalence, awareness, and the effects of education. Sexuality Research and Social Policy, 12(4), 261-272. doi: 10.1007/s13178-015-0191-z

Dacin, M. T., Munir, K., \& Tracey, P. (2010). Formal Dining at Cambridge Colleges: Linking Ritual Performance and Institutional Maintenance. Academy of Management Journal, 53(6), 1393-1418. doi: 10.5465/AMJ.2010.57318388

Degn, L., \& Sørensen, M. P. (2015). From collegial governance to conduct of conduct: Danish universities set free in the service of the state. Higher Education, 69(6), 931-946. doi: 10.1007/s10734-014-9814-1

Distatis. (2018). Facts and figures: society and state. Retrieved from https://www.destatis.de/EN/ FactsFigures/SocietyState

DIW (2018). Statistics: Education and family. Retrieved from: https://www.diw.de/en/diw_01.c.377336.en

Drape, T. A., Rudd, R., Lopez, M., \& Radford, D. (2016). Challenges and solutions to higher education institutions in Africa. International Journal of Education, 8(1), 43-58. doi: 10.5296/ije.v8i1.8742

Fägerlind, I., \& Saha, L. J. (2016). Education and national development: A comparative perspective. Elsevier.

Ferrer, A., \& Riddell, W. C. (2008). Education, credentials, and immigrant earnings. Canadian Journal of Economics, 41(1), 186-216. doi: 10.1111/j.1365-2966.2008.00460.x

Fuller, S. (2009). The Sociology of Intellectual Life: The Career of the Mind in and around the Academy. London: SAGE Publications. doi:10.4135/9781446214060

Gennaioli, N., La Porta, R., Lopez-de-Silanes, F., \& Shleifer, A. (2012). Human capital and regional development. The Quarterly journal of economics, 128(1), 105-164. doi:10.1093/qje/qjs050

Gerber, E. R., \& Gibson, C. C. (2009). Balancing Regionalism and Localism: How Institutions and Incentives Shape American Transportation Policy. American Journal of Political Science, 53(3), 633-648. doi: 10.1111/j.15405907.2009.00391.x

Glaeser, E.L., \& Lu, M. (2018). Human-Capital Externalities in China, NBER Working Paper No.24925, August 2018. Retrieved from: https://www.nber.org/papers/w24925.

Guerrero, M., Cunningham, J. A., \& Urbano, D. (2015). Economic impact of entrepreneurial universities' activities: An exploratory study of the United Kingdom. Research Policy, 44(3), 748-764. doi: 10.1016/j.respol.2014.10.008

Gulicheva, E., \& Osipova, M. (2017). Program-target method of pricing for international educational services. Czech Journal of Social Sciences, Business and Economics, 6(1), 21-27. doi:10.24984/cjssbe.2017.6.1.3

Gunter, A., \& Raghuram, P. (2018). International study in the global south: linking institutional, staff, student and knowledge mobilities. Globalisation, Societies and Education, 16(2), 192-207. doi: 10.1080/14767724.2017.1401453

Harman, G., \& Harman, K. (2003). Institutional Mergers in Higher Education: Lessons from International Experience. Tertiary Education and Management, 9(1), 29-44. doi: 10.1023/A:102226140980

Hegarty, N. (2014). Where we are now - the presence and importance of international students to universities in the United States. Journal of International Students, 4(3), 223-235.

Hinton, M., Francis, G., \& Holloway, J. (2000). Best practice benchmarking in the UK. Benchmarking: An International Journal, 7(1), 52-61. doi: 10.1108/14635770010314954

Hodgson, G. M. (2003). The hidden persuaders: institutions and individuals in economic theory. Cambridge Journal of Economics, 27(2), 159-175. doi: 10.1093/cje/27.2.159

Hüther, O., \& Krücken, G. (2018). Higher Education in Germany - Recent Developments in an International Perspective. Springer International Publishing. 
Kriaa, F., \& Bouhari, M. (2018). Characterizing the school-to-work transitions of young men and women in Tunisia. Economics, Management And Sustainability, 3(2), 85-106. doi:10.14254/jems.2018.3-2.7

Lazányi, K., Čepel, M., \& Bilan, S. (2017). Comparison of Trust and Social Relations among Students in Russian and Hungarian Higher Education. Economics \& Sociology, 10(4), 162-174.

Li, W., Sadick, M. A., Musah, A. A. I., \& Mustapha, S. (2018). The Moderating Effect of Social Innovation in Perspectives of Shared Value Creation in the Educational Sector of Ghana. Sustainability, 10(11), 4216. doi:10.3390/su10114216

Marozau, R., Guerrero, M., \& Urbano, D. (2016). Impacts of universities in different stages of economic development. Journal of the Knowledge Economy, 1-21. doi: 10.1007/s13132-016-0359-7

McKelvey, M., \& Zaring, O. (2018). Co-delivery of social innovations: exploring the university's role in academic engagement with society. Industry and Innovation, 25(6), 594-611. doi: 10.1080/13662716.2017.1295364

Mincer, J. (1974). Schooling, Experience and Earnings. Columbia University Press: New York

Mincer, J., \& Polachek, S. (1978). An exchange: the theory of human capital and the earnings of women: women's earnings reexamined. The Journal of Human Resources, 13(1), 118-134. doi: 10.2307/145305

Moretti, E. (2004). Worker's Education, Spillovers, and Productivity: Evidence from Plant-Level Production Functions. American Economic Review, 94, 656-690. doi: 10.1257/0002828041464623

Naushad, M. (2018). A study on the antecedents of entrepreneurial intentions among Saudi students. Entrepreneurship and Sustainability Issues, 5(3), 600-617. doi: 10.9770/jesi.2018.5.3(14)

Naushad, M., Faridi, M.R., \& Syed, A. M. (2018). Economic development of community by entrepreneurship: an investigation of the entrepreneurial intent and the institutional support to the local community in Al-Kharj region. Entrepreneurship and Sustainability Issues, 5(4), 899-913. doi: 10.9770/jesi.2018.5.4(14)

Navaretti, G. B., Dasgupta, P., Maler, K.-G., \& Siniscalco, D. (1998). Creation and Transfer of Knowledge: Institutions and Incentives. Springer Berlin Heidelberg.

Nuamah, S. A. (2018). Achievement Oriented: Developing Positive Academic Identities for Girl Students at an Urban School. American Educational Research Journal, 55(6), 1307-1338. doi: 10.3102/0002831218782670

Olson, M. (1995). The Devolution of the Nordic and Teutonic Economies. The American Economic Review, 85(2), 22-27. doi: $10.2307 / 2117885$

Ostrom, E., Gardner, R., \& Walker, J. (1994). Rules, Games, and Common-Pool Resources. University of Michigan Press, Michigan. doi: 10.3998/mpub.9739

Radwan, A. (2018). Science and innovation policies in North African Countries: Exploring challenges and opportunities. Entrepreneurship and Sustainability Issues, 6(1), 268-282. doi: 10.9770/jesi.2018.6.1(17)

Ramaley, J. A. (2014). The changing role of higher education: Learning to deal with wicked problems. Journal of Higher Education Outreach and Engagement, 18(3), 7-22.

Schoper, Y. G., Wald, A., Ingason, H. T., \& Fridgeirsson, T. V. (2018). Projectification in Western economies: A comparative study of Germany, Norway and Iceland. International Journal of Project Management, 36(1), 71-82. doi:10.1016/j.ijproman.2017.07.008

Sharma, S., \& Sharma, P. (2015). Indian Higher Education System: Challenges and Suggestions. Electronic Journal for Inclusive Education, 3(4), 6.

Sianesi, B., \& Van Reenen, J. (2013). Education and Economic Growth: A review of the literature. Journal of Economic Surveys, 17(2), 157-200. doi: 10.1111/1467-6419.00192

Simionescu, M., Ciuiu, D., Bilan, Y., \& Strielkowski, W. (2016). GDP and net migration in some eastern and southeastern countries of Europe. A panel data and Bayesian approach. Montenegrin Journal of Economics, 12(2), 161175.

Streeck, W., \& Thelen, K. (2005). Requirements for a useful concept of complementarity. Socio-Economic Review, 3(2), 363-366.

Streimikiene, D., Bilan, Y., Jasinskas, E., \& Griksaite, R. (2016). Migration Trends in Lithuania and other New EU Member States. Transformations in Business \& Economics, 15(1), 21-33.

Strielkowski, W., Kiseleva, L., \& Popova, E. (2018). Factors determining the quality of university education: students' views. Integration of Education, 22(2), 220-236. doi: 10.15507/1991-9468.091.022.201802.220-236 
Times Higher Education. (2018). the World University Rankings. Retrieved from https://www.timeshighereducation.com/world-university-rankings/2018/worldranking\#!/page/0/length/25/sort_by/rank/sort_order/asc/cols/stats.

United Nations. (2018) Human Development Data, 1990-2017. Available online: http://hdr.undp.org/en/data

Volchik, V. V. (2016). Culture, Behavioral Patterns and Inductive Reasoning. Journal of Institutional Studies, 8(4), $28-39$. doi: 10.17835/2076-6297.2016.8.4.028-039

Volchik, V., Klimenko, L., \& Posukhova, O. (2018). Socio-economic sustainable development and the precariat: a case study of three Russian cities. Entrepreneurship and Sustainability Issues, 6(1), 411-428. doi:10.9770/jesi.2018.6.1(25)

Yu, M. C., Wu, Y. C. J., Alhalabi, W., Kao, H. Y., \& Wu, W. H. (2016). ResearchGate: An effective altmetric indicator for active researchers? Computers in Human Behavior, 55, 1001-1006. doi:10.1016/j.chb.2015.11.007

Zairi, M. (2010). Benchmarking for best practice, Routledge, London.

Zilber, T. B. (2009). Institutional maintenance as narrative acts. In: T. B. Lawrence, R. Suddaby, \& B. Leca (eds.) Institutional Work, Cambridge: Cambridge University Press, pp. 205-235. doi:10.1017/CBO9780511596605.008 